\title{
Aggregate Efficiency of Higher Education Management under Coordination of Private Universities Area Using DEA in Determining Strategic Innovation
}

\author{
Rorim Panday \\ Bhayangkara Jaya University, Management, Jakarta, Indonesia \\ Email: indripan@gmail.com
}

\begin{abstract}
It should be 3078 higher education institutions in Indonesia, with student population of approximately 6.7 million people, which consists of five types institutions, namely: university, institute, colleges, academy and polytechnic. Ministry of education and culture management divided the management of higher education into 12 regions of coordination of private universities (Kopertis). Each Kopertis region had a number higher education institutions, number of lecturers and students in varying number. The number of faculty qualifications by level of education also vary from educated of D3(diploma) up to S3(doctoral). As a result of the learning process, also produced varying the number of graduates. With the variety of input factors in producing graduates as output factors, as aggregate in Kopertis region, as relatively, is there any area of Kopertis that has not been efficient implementation?. By using Data Envelopment Analysis (DEA), it is resulting three Kopertis regions obtained efficient in managing of public higher education and six Kopertis region efficient in managing of private higher education. From the findings of this study, for kopertis has not been efficient in managing, it will be determined strategic innovation in order to improve the efficiency in managing of higher education institutions under kopertis.
\end{abstract}

Keywords: Efficinency, Data envelopment analysis, kopertis 


\section{INTRODUCTION}

Indonesia population approximately 230 million people, has 3078 higher education institution (Pusat Data, 2012), which consists of five types institutions, namely: university, institute, colleges, academy and polytechnic. The number of registered students were 5.616.670 people, 1.142 .835 people as new students, while only 738.260 people graduated (data of $2011 / 2012$ ), means only approximately $10.9 \%$ of the total number of students. In this case the output that comes out is still far below the student input. So that as the aggregate, only reached $64.6 \%$ efficiency. It is easy to understand, because of the variability in the quality of higher education that are represented at the level of accreditation of higher education at study program and institutional level. Coupled with the quality of the new students entry. From the data BAN-PT (BAN-PT website, 2015), at least 163 higher education institutions that have been accredited institution, in percentage was 5.3\%. And besides that there were still thousands of study program who had not been A or B accredited. For that, we need some strategic innovation to improve institutional accreditation and study programs accreditation. Here strategic innovation needs to be developed from the study program, higher education institutions up to the Kopertis and ministry of education and culture.

Education is essentially a production system, involving a transformation process which produces quality graduates as an effective workforce, as well as research and community service (Panday, 2014). In the educational process, requiring a variety of factors of production inputs such as educational institutions, faculties, curriculum and syllabus, facilities and infrastructure, non-educational personnel to produce quality graduates. The production process of the higher education system can be described in Figure-1 (Panday, 2014). To run the production system, each institution of higher education has varies greatly in its management, because has various constraints such as lack of fulltime faculties, limited funds to support the educational process, limited of facilities and infrastructure, so that produce graduates who are diverse in terms of quality and quantity.

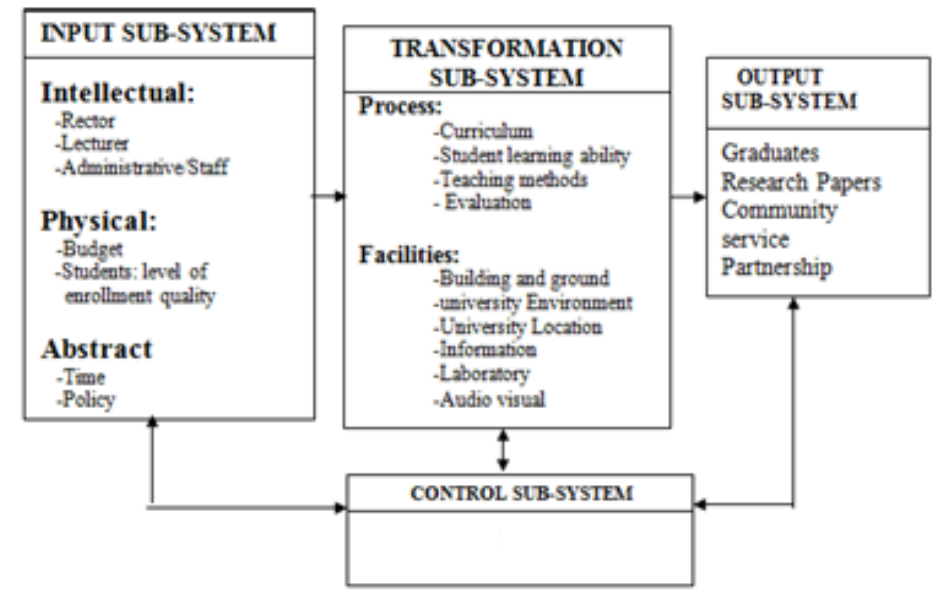

Figure-1. Higher education Input-Proses-Output System

For those reasons, the ministry of education and culture, has issued various regulations that strengthen national education legislation and law of teachers and lecturers, so that each institution of higher education become to high-quality education and producing quality graduates. The government has determined 8 
standards of education, there were (Standar Nasional Pendidikan, 2005): standard of content, standard of process, standard of management, standards of lecturer and staff, standard of facilities and infrastructure, standards of financing, standards of graduates and the standards of research and community service. For the standard of lecturer, the government required a minimum educational qualification as S2 educated in their field (Undang-undang Guru dan Dosen, 2005), has a National Lecturer Identification Number (NIDN), and has a functional position. The faculty who are taking classes S2 (masteral degree) and S3 (doctoral deghree) are required to publish their research in international journals (Sistem Pendidikan Nasional, 2003). All requirements to be a lecturer, force feeling in the current is that burdensome for lecturers and of course also for higher education institutions.

As illutrated, education data in Indonesia presented at Table 1 to Table 5 which have been derived from (Pusat data, 2012). The amount of existing universities can be seen in Table 1, which also shown that most higher education institutions in Indonesia are Academies and Colleges. Out of 478 universities, 52 are public Universities, while the rest 426 are managed privately.

Table-1 Type and number of higher education in Indonesia

\begin{tabular}{|c|c|c|c|}
\hline $\begin{array}{c}\text { Types of } \\
\text { higher } \\
\text { education }\end{array}$ & $\begin{array}{c}\text { Total of } \\
\text { higher } \\
\text { education }\end{array}$ & $\begin{array}{c}\text { Number } \\
\text { of public } \\
\text { higher } \\
\text { education }\end{array}$ & $\begin{array}{c}\text { Number } \\
\text { of private } \\
\text { higher } \\
\text { education }\end{array}$ \\
\hline University & 478 & 52 & 426 \\
\hline Academy & 1094 & 0 & 1094 \\
\hline Institute & 57 & 7 & 50 \\
\hline Polytechnic & 175 & 32 & 143 \\
\hline Colleges & 1366 & 1 & 1365 \\
\hline Total & 3170 & 92 & 3078 \\
\hline
\end{tabular}

The number of lecturers for higher education institutions is shown in Table 2.

Table-2 Number of lecturers at public and private $\mathrm{HE}$

\begin{tabular}{|c|c|c|c|}
\hline $\begin{array}{c}\text { Types of } \\
\text { higher } \\
\text { education }\end{array}$ & $\begin{array}{c}\text { Total of } \\
\text { lecturer }\end{array}$ & $\begin{array}{c}\text { Number } \\
\text { of lecturer } \\
\text { in public } \\
\text { HE }\end{array}$ & $\begin{array}{c}\text { Number } \\
\text { of lecturer } \\
\text { in private } \\
\text { HE }\end{array}$ \\
\hline University & 115.232 & 48.119 & 67.113 \\
\hline Academy & 16.423 & 0 & 16.423 \\
\hline Institute & 8.924 & 3.844 & 5.080 \\
\hline Polytechnic & $10-.234$ & 5.898 & 4.336 \\
\hline Colleges & 42.131 & 117 & 42.014 \\
\hline Total & 192.944 & 57.978 & 134.966 \\
\hline
\end{tabular}

There are 192.944 lecturers and with approximately 6.759 .505 students, thus, the ratio of lecturers to students is 1: 35 Considering that the average provision ratio is $1: 30$, this condition didn't fulfil the requirement, but in reality, the ratio varies at each university. However, when taking into account educational background accordance to 
laws of teachers and lecturers, eligible lecturers are limited to those with masters or doctoral degrees, including specialist-1 and specialist-2, so that the lecturer to student ratio becomes ineligible according to the National Education Standard (NES) (Standar Nasional Pendidikan, 2005).

To meet the requirements in managing the higher education, still very many institution which do not meet these requirements. However, education must remain running.

Easy to see efficiency, can be calculated from the number of students entering and graduating. Number new student in table-3, number registered student in table- 4 and number of graduate student in table- 5 .

Table-3 Number of new student at public and private HE

\begin{tabular}{|c|c|c|c|}
\hline $\begin{array}{c}\text { Types of higher } \\
\text { education }\end{array}$ & $\begin{array}{c}\text { Total of new } \\
\text { student }\end{array}$ & $\begin{array}{c}\text { Number of } \\
\text { new student } \\
\text { in public HE }\end{array}$ & $\begin{array}{c}\text { Number of new } \\
\text { student in } \\
\text { private HE }\end{array}$ \\
\hline University & 817.979 & 453.013 & 364.966 \\
\hline Academy & 79.249 & 0 & 79.249 \\
\hline Institute & 60.269 & 22.815 & 37.454 \\
\hline Polytechnic & 39.378 & 20.854 & 18.524 \\
\hline Colleges & 145.960 & 350 & 145.610 \\
\hline Total & 1.142 .835 & 497.032 & 645.803 \\
\hline
\end{tabular}

In the new admissions, private higher education students receive much more than the public higher education.

Table-4 Number of registered student at public and private $\mathrm{HE}$

\begin{tabular}{|c|c|c|c|}
\hline $\begin{array}{c}\text { Types of higher } \\
\text { education }\end{array}$ & $\begin{array}{c}\text { Total of } \\
\text { registered } \\
\text { student }\end{array}$ & $\begin{array}{c}\text { Number of } \\
\text { registered } \\
\text { student in } \\
\text { public HE }\end{array}$ & $\begin{array}{c}\text { Number of } \\
\text { registered } \\
\text { student in } \\
\text { private HE }\end{array}$ \\
\hline University & 3.629 .115 & 1.664 .737 & 1.964 .378 \\
\hline Academy & 360.713 & 0 & 360.713 \\
\hline Institute & 228.437 & 74.587 & 153.850 \\
\hline Polytechnic & 159.147 & 76.033 & 83.114 \\
\hline Colleges & 1.239 .258 & 1.034 & 1.238 .224 \\
\hline Total & 5.616 .670 & 1.816 .391 & 3.800 .279 \\
\hline
\end{tabular}

At private higher education, student has registered almost twice than at the public higher education. It seen, private higher education has a greater capacity than public higher education capacity. Efficient of public higher education graduates is $66.04 \%$, while the efficiency of private higher education is $63.49 \%$. Efficiency here is only calculated from graduate students to new students, not taking into account other of production inputs factors in the educational process. 
Table-5 Number of student graduate at public and private $\mathrm{HE}$

\begin{tabular}{|c|c|c|c|}
\hline $\begin{array}{c}\text { Types of higher } \\
\text { education }\end{array}$ & $\begin{array}{c}\text { Total of } \\
\text { student } \\
\text { graduate }\end{array}$ & $\begin{array}{c}\text { Number of } \\
\text { student } \\
\text { graduate in } \\
\text { public HE }\end{array}$ & $\begin{array}{c}\text { Number of } \\
\text { student } \\
\text { graduate in } \\
\text { private HE }\end{array}$ \\
\hline University & 521.218 & 300.468 & 220.750 \\
\hline Academy & 45.988 & 0 & 45.988 \\
\hline Institute & 28.267 & 11.810 & 16.457 \\
\hline Polytechnic & 26.359 & 15.850 & 10.509 \\
\hline Colleges & 116.428 & 113 & 116.315 \\
\hline Total & 738.260 & 328.241 & 410.019 \\
\hline
\end{tabular}

Seeing efficiency is still less than one (1) or less than $100 \%$, its indication, any other of production inputs factors that have not been used optimally.

Coordination of private universities (Kopertis), assist, supervise and monitor the course of higher education in each Kopertis region. With the imperfections in the management department at each institution of higher education, as aggregate, it is very interesting to study, how the aggregate efficiency between regions of Kopertis in producing graduates of higher education as relatively?

\section{REVIEW OF LITERATURE}

Efficiency is often associated with the performance of an organization because efficiency reflects the ratio between the output to the input. In the many literatures, the efficiency is also often associated with productivity because both are equally variable rate input to output. Understanding productivity in contrast with the notion of efficiency. Productivity is calculated by dividing the output to input, while the efficiency is input divided by output. Figure 1 illustrates the relationship between inputs, processes and outputs in calculate of efficiency and productivity.

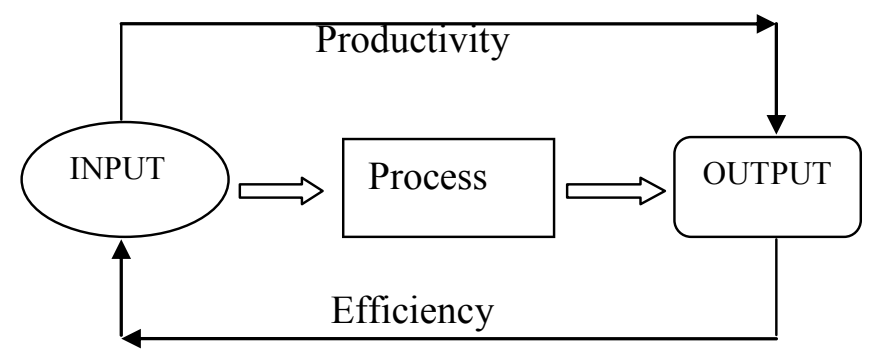

Figure-2 Input dan Output relation

Efficiency and productivity is an index that shows the results of the comparison between the output and input. Both of these ratios indicate that the efficiency or productivity index can be controlled by manipulating the input or output management, or even both at once. Efficiency and productivity can be used to measure the performance of various activities both economic activity, social, cultural etc. Efficiency in an effort to achieve maximum results with the use of available resources, which include natural resources, capital, and people within a certain time. An activity can be called efficient if attempts have been made, providing maximum output, both of quantity and quality. An activity can also be said to be efficient if the minimum 
effort can achieve a certain output. Effort encompasses the material, mind, physical energy, space, and time. Efficiency is the ratio between the output to the input. In addition there is an optimum efficiency is the best ratio between output and input. According Yazar Oscan A. (2008), the concept of efficiency can be translated into technical efficiency, the efficiency of scale (scale efficiency), cost efficiency (price efficiency) and allocative efficiency. Measurement of efficiency can be done by various methods, namely ratio analysis, least-squares regression (LSR), total factor productivity (TFP), stochastic frontier analysis (SFA), and data envelopment analysis (DEA). Of all the ways the calculation efficiency, DEA is the most appropriate method for this study, because the DEA uses many inputs and many outputs.

\section{Data Envelopment Analysis}

Data Envelopment Analysis (DEA) is a non-parameter approach to evaluate the performance of a set of homogeneous entities called Decision Making Units (DMU) where there are lots of inputs and outputs, each of which have different weights (weighted multiple inputs and weighted multiple outputs). This method was first discovered by Charnes, Cooper and Rhodes (CCR) (Charnes et al., 1978) with the aim to maximize the efficiency of DMU are assessed from some set of entities. The term decision making units can be used to represent non-profit institutions such as schools, hospitals, government output of the institution will usually difficult to quantify the value of money.

In this study, the DMU will represent Kopertis. The weights of each input and output is very varied, which is determined from the importance of the input and output of the DMU.

DMU will have a value of $100 \%$ efficiency when there is the most forward position. Comparative efficiency value will be provided by the DEA following conclusions and efficiency of each DMU. Efficiency and productivity assessment factors are influenced by the input and output variable amount. The calculation of the efficiency of Universities mostly apply Data Envelopment Analysis (DEA) (Ahn et al., 1988).

If there are four imput which becomes the input of the DEA then there are four linear programming equations to be solved for each DMU (in this case is Kopertis) to determine the distance:

$$
\left.\begin{array}{c}
D_{0}^{t}\left[x^{t+1}, u^{t+1} / \operatorname{CRTS}\right]^{-1}=\operatorname{Max} \lambda \\
\text { Subject tuntuk } \sum \lambda_{\mathrm{i}} \mathrm{x}_{\mathrm{i}}^{\mathrm{t}} \leq \mathrm{x}^{\mathrm{t}+1} \\
\sum_{\lambda \geq 0} \lambda_{\mathrm{i}} \mathrm{u}_{\mathrm{i}}^{\mathrm{t}} \geq \lambda \mathrm{u}^{\mathrm{t}+1}
\end{array}\right\}
$$


$D_{0}^{t+1}\left[x^{t}, u^{t} / \text { CRTS }\right]^{-1}=\operatorname{Max} \lambda$

Subject untuk $\sum \lambda_{i} x_{i}^{t} \leq x^{t}$

$$
\sum_{\lambda \geq 0} \lambda_{\mathrm{i}} \mathrm{u}_{\mathrm{i}}^{\mathrm{t}} \geq \lambda \mathrm{u}^{\mathrm{t}}
$$

$\mathrm{D}_{0}^{\mathrm{t}+1}\left[\mathrm{x}^{\mathrm{t}+1}, \mathrm{u}^{\mathrm{t}+1} / \mathrm{CRTS}^{-1}=\operatorname{Max} \lambda\right.$

subjectuntuk $\sum \lambda_{\mathrm{i}} \mathrm{x}_{\mathrm{i}}^{\mathrm{t}+1} \leq \mathrm{x}^{\mathrm{t}+1}$

$$
\sum_{\lambda \geq 0} \lambda_{i} u_{i}^{t+1} \geq \lambda u^{t+1}
$$

$\mathrm{D}_{0}^{\mathrm{t}}\left[\mathrm{x}^{\mathrm{t}}, \mathrm{u}^{\mathrm{t}} / \mathrm{CRTS}\right]^{-1}=\operatorname{Max} \lambda$

subjectuntuk $\sum \lambda_{\mathrm{i}} \mathrm{x}_{\mathrm{i}}^{\mathrm{t}} \leq \mathrm{x}^{\mathrm{t}}$

$$
\sum_{\lambda \geq 0} \lambda_{\mathrm{i}} \mathrm{u}_{\mathrm{i}}^{\mathrm{t}} \geq \lambda \mathrm{u}^{\mathrm{t}}
$$

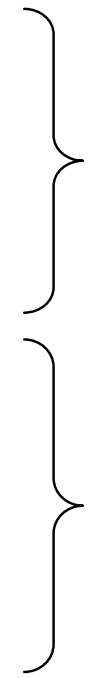

Where $\mathrm{K}, \mathrm{N}, \mathrm{M}$, and $\mathrm{T}$ represent number of kopertis, input, output and time periode of sample. In this study $\mathrm{K}=12, \mathrm{~N}=8, \mathrm{M}=1$ and $\mathrm{T}=1$, Time Period: $\mathrm{t}=2011$ and $\lambda$ 's is intencity parameter. To twelve linear equations required for each unit of production (total production of each Kopertis of this study). DEA has been widely used in various organizations or companies to measure the efficiency of organizations / companies. Several studies relating to the use of DEA on educational issues conducted by Handaru Jati. (April, 2015), using DEA to assess the efficiency of the University LPTK in Indonesia, Martin Flégl \& Kristýna Vltavská(2013) measure the Efficiency at Faculties of Economics in the Czech Public Higher Education Institutions, Zara Daghbashyan(2011) using DEA in The Economic Efficiency of Swedish Higher Education Institutions, Emilio Martin (2003), applying the Data Envelopment Analysis Methodology in the Performance Assessment of the Zaragoza University Departments, Altamirano-Corro et al (2012), have measured the institutional efficiency using data envelopment analysis and analytic hierarchy process in the case of a Mexican University.

\section{METHODOLOGY}

This study used Data Envelopment Analysis. The data used are secondary data from Indonesian education statistics report for the period 2011-2012. The data collected were data of number of higher education institutions, number of new students, number of students registered, number of graduates, number of lecturers, number of lecturers with D3, number of lecturers with S1 / D4(bachelor degree/ Diploma), number of lecturer with S2(masteral degree), number of lecturer with S3(doctoral degree), number of lecturers with SP(Specialist), number of lecturers with Profession and the amount of part timer lecturer for each kopertis region. All these data are grouped in Kopertis region. The data will be made and calculated in four files: 
1. Scenario-1, the cumulative data across higher education (public and private)

2. Scenario-2, public higher education data only

3. Scenario-3, private higher education data only

4. Scenario-4, public higher education data and private higher education data

Thus there are four results will count of the efficiency.

All data, input and output variables are defined as follows:

Tabel-6 Variable name and variable orientation

\begin{tabular}{|l|l|l|}
\hline Variable Name & Variable orientation & Variable type \\
\hline Number of institution & INPUT & STANDARD \\
\hline Number of New student & INPUT & STANDARD \\
\hline Number of Student registered & INPUT & STANDARD \\
\hline Number of Graduates & OUTPUT & STANDARD \\
\hline Number of Lecturer & INPUT & STANDARD \\
\hline Number of D3 Lecturer & INPUT & STANDARD \\
\hline Number of D4/S1 Lecturer & INPUT & STANDARD \\
\hline Number of S2 Lecturer & INPUT & STANDARD \\
\hline Number of S3 Lecturer & INPUT & STANDARD \\
\hline Number of Sp Lecturer & INPUT & STANDARD \\
\hline Number of Profesion Lecturer & INPUT & STANDARD \\
\hline Number of Part time Lecturer & INPUT & STANDARD \\
\hline
\end{tabular}

Calculation of relative efficiency using software OSDEA (Open Software Data Envelopment Analysis). This study is limited to the technical efficiency.

\section{RESULT AND DISCUSSION}

From data collection, tabulated in the table, presented at the attachment of this paper. Results of aggregate efficiency of the management of higher education in Indonesia in each of Kopertis area shown in the table-7.

Table-7 Computation result of efficiency for each scenario

\begin{tabular}{|l|l|l|l|l|l|}
\hline & Scenario-1 & Scenario -2 & Scenario -3 & \multicolumn{2}{|l|}{ Scenario -4 } \\
\hline & Total HE & Public HE & Private HE & \multicolumn{2}{|l|}{ Public + Private HE } \\
\hline $\begin{array}{l}\text { DMU } \\
\text { Name }\end{array}$ & Objective & $\begin{array}{l}\text { Objective } \\
\text { Value }\end{array}$ & $\begin{array}{l}\text { Objective } \\
\text { Value }\end{array}$ & $\begin{array}{l}\text { Objective } \\
\text { Value }\end{array}$ & $\begin{array}{l}\text { Objective } \\
\text { Value }\end{array}$ \\
\hline kopertis-1 & 0,907444305 & 0,775052129 & 1 & 0,775052129 & 1 \\
\hline kopertis-2 & 1 & 0,898662698 & 1 & 0,898662698 & 0,973639954 \\
\hline kopertis-3 & 1 & 1 & 1 & 1 & 0,713763143 \\
\hline kopertis-4 & 0,98571232 & 0,910175812 & 0,866388724 & 0,910175812 & 0,800418134 \\
\hline kopertis-5 & 1 & 0,811510086 & 1 & 0,811510086 & 1 \\
\hline kopertis-6 & 1 & 0,69140696 & 1 & 0,690250501 & 1 \\
\hline kopertis-7 & 0,834076162 & 0,661017792 & 1 & 0,661017792 & 0,95982266 \\
\hline kopertis-8 & 0,999285264 & 0,614438341 & 1 & 0,614438341 & 1 \\
\hline kopertis-9 & 0,93423763 & 0,74185278 & 0,947161098 & 0,74185278 & 0,947161098 \\
\hline kopertis-10 & 1 & 0,933724044 & 0,88929505 & 0,933724044 & 0,850561765 \\
\hline kopertis-11 & 1 & 1 & 1 & 1 & 1 \\
\hline kopertis-12 & 1 & 1 & 1 & 1 & 1 \\
\hline
\end{tabular}


In table 7, shown that management of higher education in each Kopertis region, which is efficient for each scenario, providing the efficiency value as 1 . While in-efficiency has a value less than 1. In Scenario 1, for the cumulative data of higher education, in terms of managing of higher education, Kopertis regions that had have efficient, are 7 areas, namely: Kopertis-2, Kopertis-3, Kopertis-5, Kopertis-6, Kopertis-10, Kopertis11 and Kopertis-12. Five Kopertis of the rest have not efficient. In this study, mean 7 Kopertis those are efficient, it is efficient in terms of use of production inputs factors, namely the number of higher education, the number of faculty and number of student as shown in the slack table below:

Table-8 Slack of Scenario -1

\begin{tabular}{|l|c|c|c|c|c|c|}
\hline DMU Name & $\begin{array}{c}\text { Number of } \\
\text { Institution }\end{array}$ & $\begin{array}{c}\text { New } \\
\text { Student }\end{array}$ & $\begin{array}{c}\text { Registered } \\
\text { student }\end{array}$ & Graduate & $\begin{array}{c}\text { Number of } \\
\text { Lecturer }\end{array}$ & $\begin{array}{c}\text { D3 } \\
\text { Lecturer }\end{array}$ \\
\hline kopertis-1 & 237,81 & 0 & $222.931,78$ & 0 & $12.443,27$ & 123,89 \\
\hline kopertis-2 & 0 & 0 & 0 & 0 & 0 & 0 \\
\hline kopertis-3 & 0 & 0 & 0 & 0 & 0 & 0 \\
\hline koperttis-4 & 112,95 & 0 & $97.336,17$ & 0 & $7.254,41$ & 51,29 \\
\hline kopertis-5 & 0 & 0 & 0 & 0 & 0 & 0 \\
\hline kopertis-6 & 0 & 0 & 0 & 0 & 0 & 0 \\
\hline kopertis-7 & 57,45 & 0 & $72.782,38$ & 0 & $7.731,87$ & 22,63 \\
\hline kopertis-8 & 75,21 & 0 & $103.453,69$ & 0 & $7.029,39$ & 0 \\
\hline kopertis-9 & 60,43 & 0 & $109.992,79$ & 0 & $4.859,06$ & 0 \\
\hline kopertis-10 & 0 & 0 & 0 & 0 & 0 & 0 \\
\hline kopertis-11 & 0 & 0 & 0 & 0 & 0 & 0 \\
\hline kopertis-12 & 0 & 0 & 0 & 0 & 0 & 0 \\
\hline
\end{tabular}

(continue of table-8)

\begin{tabular}{|l|c|c|c|c|c|c|}
\hline DMU Name & $\begin{array}{c}\text { D4S1 } \\
\text { Lecturer }\end{array}$ & $\begin{array}{c}\text { S2 } \\
\text { Lecturer }\end{array}$ & $\begin{array}{c}\text { S3 } \\
\text { Lecturer }\end{array}$ & $\begin{array}{c}\text { Sp } \\
\text { Lecturer }\end{array}$ & $\begin{array}{c}\text { profesi } \\
\text { Lecturer }\end{array}$ & $\begin{array}{c}\text { Part timer } \\
\text { Lecturer }\end{array}$ \\
\hline kopertis-1 & $4.623,53$ & $3.081,90$ & 139,43 & 41,71 & 190,94 & $4.241,87$ \\
\hline kopertis-2 & 0 & 0 & 0 & 0 & 0 & 0 \\
\hline kopertis-3 & 0 & 0 & 0 & 0 & 0 & 0 \\
\hline koperttis-4 & $2.100,89$ & $1.966,54$ & $1.845,95$ & 0 & - & $1.304,04$ \\
\hline kopertis-5 & 0 & 0 & 0 & 0 & 0 & 0 \\
\hline kopertis-6 & 0 & 0 & 0 & 0 & 0 & 0 \\
\hline kopertis-7 & $1.158,40$ & $4.163,33$ & 889,67 & 0 & 49,97 & $1.364,45$ \\
\hline kopertis-8 & $2.009,33$ & $3.568,21$ & 465,73 & 0 & 84,62 & 901,99 \\
\hline kopertis-9 & $1.905,02$ & $1.520,68$ & 720,93 & 0 & 127,54 & 586,09 \\
\hline kopertis-10 & 0 & 0 & 0 & 0 & 0 & 0 \\
\hline kopertis-11 & 0 & 0 & 0 & 0 & 0 & 0 \\
\hline kopertis-12 & 0 & 0 & 0 & 0 & 0 & 0 \\
\hline
\end{tabular}

In scenario 1, the factor that efficient in use of production inputs is the number of new students, it seen from slack value equal to zero are related with factors of production output is the number of students graduate.

At slack table, which contains zero, meaning the use of production factors is efficient, while if not zero, meaning the use of production inputs factors inefficient. The number listed for that have not efficient is the residual / slack of the production inputs factors. 
This can be interpreted as relatively to scenario 1 , there are the production factors have not efficient to use in the five Kopertis regions.

In scenario 2, where the calculation of the efficiency of the data only for public higher education. Computation results shown only 3 Kopertis regions have efficient those are Kopertis-3, Kopertis-11 and Kopertis-12. Whereas for other Kopertis shown have not efficient.

Table-9. Slack of Scenario -2

\begin{tabular}{|l|c|c|c|c|c|c|}
\hline DMU Name & $\begin{array}{c}\text { Number of } \\
\text { institution }\end{array}$ & $\begin{array}{c}\text { New } \\
\text { Student }\end{array}$ & $\begin{array}{c}\text { Registerd } \\
\text { student }\end{array}$ & Graduate & D3 lecturer & $\begin{array}{c}\text { D4S1 } \\
\text { Lecturer }\end{array}$ \\
\hline kopertis-1 & 4,03 & 0 & $15.781,29$ & 0 & 1,55 & 405,55 \\
\hline kopertis-2 & 2,44 & $2.045,44$ & $14.813,71$ & 0 & 10,01 & 0 \\
\hline kopertis-3 & 0 & 0 & 0 & 0 & 0 & 0 \\
\hline koperttis-4 & 0,37 & $6.370,99$ & 0 & 0 & 4,27 & 175,01 \\
\hline kopertis-5 & 1,94 & 0 & $18.772,94$ & 0 & 2,43 & 169,12 \\
\hline kopertis-6 & 3,47 & 0 & $16.058,59$ & 0 & 3,44 & 214,62 \\
\hline kopertis-7 & 6,46 & 0 & $28.836,85$ & 0 & 0 & 370,50 \\
\hline kopertis-8 & 4,58 & 0 & $7.201,43$ & 0 & 1,23 & 275,07 \\
\hline kopertis-9 & 4,49 & 0 & $15.622,69$ & 0 & 3,47 & 590,75 \\
\hline kopertis-10 & 3,20 & 132,17 & $24.987,72$ & 0 & 2,18 & 0 \\
\hline kopertis-11 & 0 & 0 & 0 & 0 & 0 & 0 \\
\hline kopertis-12 & 0 & 0 & 0 & 0 & 0 & 0 \\
\hline
\end{tabular}

(continue of table-9)

\begin{tabular}{|l|c|c|c|c|c|c|}
\hline DMU Name & $\begin{array}{c}\text { S2 } \\
\text { Lecturer }\end{array}$ & $\begin{array}{c}\text { S3 } \\
\text { Lecturer }\end{array}$ & $\begin{array}{c}\text { Sp } \\
\text { Lecturer }\end{array}$ & $\begin{array}{c}\text { Profesi } \\
\text { Lecturer }\end{array}$ & $\begin{array}{c}\text { Part timer } \\
\text { Lecturer }\end{array}$ & $\begin{array}{c}\text { Number of } \\
\text { Lecturer }\end{array}$ \\
\hline kopertis-1 & $2.109,69$ & 388,43 & 109,54 & 143,29 & 0,48 & $3.158,54$ \\
\hline kopertis-2 & 881,50 & 293,07 & 0 & 34,02 & 0 & $1.218,60$ \\
\hline kopertis-3 & 0 & 0 & 0 & 0 & 0 & 0 \\
\hline koperttis-4 & $1.651,83$ & $1.604,27$ & 0 & 25,35 & 0 & $3.460,74$ \\
\hline kopertis-5 & $1.458,99$ & 733,77 & 42,83 & 1,11 & 1,17 & $2.409,42$ \\
\hline kopertis-6 & $2.385,08$ & 503,95 & 0 & 46,76 & 2,72 & $3.156,57$ \\
\hline kopertis-7 & $2.681,77$ & 839,12 & 74,09 & 113,50 & 9,82 & $4.088,80$ \\
\hline kopertis-8 & $1.762,88$ & 353,01 & 14,09 & 50,27 & 1,03 & $2.457,58$ \\
\hline kopertis-9 & $2.649,33$ & 760,87 & 0 & 112,39 & 0 & $4.191,00$ \\
\hline kopertis-10 & $1.047,01$ & 453,02 & 0 & 70,12 & 0 & $1.572,33$ \\
\hline kopertis-11 & 0 & 0 & 0 & 0 & 0 & 0 \\
\hline kopertis-12 & 0 & 0 & 0 & 0 & 0 & 0 \\
\hline
\end{tabular}

In table 9, slack of scenario-2, it seen, production inputs factors that efficient use are having a slack value of zero, while the use of production input factors that have not efficient, it slack value not equal to zero. The smallest slack is number of institutions, the number of lecturers with D3 and number of part-time lecturers, means the use of a third factors of production are already nearly efficient among public universities.

In scenario 3, where the Computation of relative efficiency among private universities, computation results indicate that 9 kopertis region have been efficient. While the rest 
kopertis region have not efficient, those are kopertis-4, kopertis- 9 and kopertis- 10 . The slack of scenario-3 at the table-10.

Tabel-10. Slack of Scenario -3

\begin{tabular}{|l|c|c|c|c|c|c|}
\hline DMU Name & $\begin{array}{c}\text { Number of } \\
\text { institution }\end{array}$ & $\begin{array}{c}\text { New } \\
\text { Student }\end{array}$ & $\begin{array}{c}\text { Registerd } \\
\text { student }\end{array}$ & Graduate & D3 lecturer & $\begin{array}{c}\text { D4S1 } \\
\text { Lecturer }\end{array}$ \\
\hline kopertis-1 & 0 & 0 & 0 & 0 & 0 & 0 \\
\hline kopertis-2 & 0 & 0 & 0 & 0 & 0 & 0 \\
\hline kopertis-3 & 0 & 0 & 0 & 0 & 0 & 0 \\
\hline koperttis-4 & 0 & 0 & $13.714,90$ & 0 & 52,86 & 33,59 \\
\hline kopertis-5 & 0 & 0 & 0 & 0 & 0 & 0 \\
\hline kopertis-6 & 0 & 0 & 0 & 0 & 0 & 0 \\
\hline kopertis-7 & 0 & 0,00 & 0,00 & 0 & 0,00 & 0,00 \\
\hline kopertis-8 & 0 & 0 & 0 & 0 & 0 & 0 \\
\hline kopertis-9 & 81,77 & $6.830,97$ & $104.129,50$ & 0 & 12,55 & 886,78 \\
\hline kopertis-10 & 54,55 & 0 & $4.521,20$ & 0 & 5,78 & 53,51 \\
\hline kopertis-11 & 0 & 0 & 0 & 0 & 0 & 0 \\
\hline kopertis-12 & 0 & 0 & 0 & 0 & 0 & 0 \\
\hline
\end{tabular}

(continue of table-10)

\begin{tabular}{|l|c|c|c|c|c|c|}
\hline DMU Name & $\begin{array}{c}\text { S2 } \\
\text { Lecturer }\end{array}$ & $\begin{array}{c}\mathrm{S} 3 \\
\text { Lecturer }\end{array}$ & $\begin{array}{c}\text { Sp } \\
\text { Lecturer }\end{array}$ & $\begin{array}{c}\text { profesi } \\
\text { Lecturer }\end{array}$ & $\begin{array}{c}\text { Part timer } \\
\text { Lecturer }\end{array}$ & $\begin{array}{c}\text { Number of } \\
\text { Lecturer }\end{array}$ \\
\hline kopertis-1 & 0 & 0 & 0 & 0 & 0 & 0 \\
\hline kopertis-2 & 0 & 0 & 0 & 0 & 0 & 0 \\
\hline kopertis-3 & 0 & 0 & 0 & 0 & 0 & 0 \\
\hline koperttis-4 & 299,81 & 318,11 & 29,03 & - & 300,63 & $1.034,03$ \\
\hline kopertis-5 & 0 & 0 & 0 & 0 & 0 & 0 \\
\hline kopertis-6 & 0 & 0 & 0 & 0 & 0 & 0 \\
\hline kopertis-7 & 0 & 0 & 0 & 0 & 0,00 & 0 \\
\hline kopertis-8 & 0 & 0 & 0 & 0 & 0 & 0 \\
\hline kopertis-9 & 328,18 & 118,35 & 0 & 49,77 & 0 & $1.395,62$ \\
\hline kopertis-10 & 0 & 0 & 0 & 49,61 & 0 & 108,90 \\
\hline kopertis-11 & 0 & 0 & 0 & 0 & 0 & 0 \\
\hline kopertis-12 & 0 & 0 & 0 & 0 & 0 & 0 \\
\hline
\end{tabular}

At the table-10, slack of scenario-3, it seen production factors of inputs that efficient use are having a slack value of zero, while the use of production input factors have not efficient, it slack value not equal to zero. If compare to scenario-2, use of production input factor at scenario-3,more better than scenario-2. As relatively, management of higher education by private higher education more efficient compared to management of higher education by public higher education.

At scenario-4, where the computation of relative efficient among public higher education and private higher education, shown there are 3 kopertis regions for public higher education that have efficient (kopertis-3, kopertis11 dan kopertis-12) and 6 kopertis regions for private higher education that have efficient (kopertis-1,kopertis5,kopertis-6, kopertis-8,kopertis-11 dan kopertis-12). Its means, there are 9 kopertis regions have efficient of 24 kopertis DMU. The slack of scenario-4 shown at table- 11. 
Tabel-11 Slack op Scenario -4

\begin{tabular}{|l|c|c|c|c|c|c|}
\hline DMU Name & $\begin{array}{c}\text { Number } \\
\text { of } \\
\text { institution }\end{array}$ & $\begin{array}{c}\text { New } \\
\text { Student }\end{array}$ & $\begin{array}{c}\text { Registerd } \\
\text { student }\end{array}$ & Graduate & $\begin{array}{c}\text { D3 } \\
\text { lecturer }\end{array}$ & $\begin{array}{c}\text { D4S1 } \\
\text { Lecturer }\end{array}$ \\
\hline kopertis-1 & 4,03 & 0 & $15.781,29$ & 0 & 1,55 & 405,55 \\
\hline kopertis-2 & 2,44 & $2.045,44$ & $14.813,71$ & 0 & 10,01 & 0 \\
\hline kopertis-3 & 0 & 0 & 0 & 0 & 0 & 0 \\
\hline koperttis-4 & 0,37 & $6.370,99$ & 0 & 0 & 4,27 & 175,01 \\
\hline kopertis-5 & 1,94 & 0 & $18.772,94$ & 0 & 2,43 & 169,12 \\
\hline kopertis-6 & 3,10 & 0 & $15.901,87$ & 0 & 3,42 & 211,30 \\
\hline kopertis-7 & 6,46 & 0 & $28.836,85$ & 0 & 0 & 370,50 \\
\hline kopertis-8 & 4,58 & 0 & $7.201,43$ & 0 & 1,23 & 275,07 \\
\hline kopertis-9 & 4,49 & 0 & $15.622,69$ & 0 & 3,47 & 590,75 \\
\hline kopertis-10 & 3,20 & 132,17 & $24.987,72$ & 0 & 2,18 & -0 \\
\hline kopertis-11 & 0 & 0 & 0 & 0 & 0 & 0 \\
\hline kopertis-12 & 0 & 0 & 0 & 0 & 0 & 0 \\
\hline kopertis-1A & 0 & 0 & 0 & 0 & 0 & 0 \\
\hline kopertis-2A & 101,09 & 0 & $85.444,09$ & 0 & 17,76 & $1.722,37$ \\
\hline kopertis-3A & 100,24 & $4.662,34$ & 0 & 0 & 96,04 & $2.796,45$ \\
\hline koperttis-4A & 58,12 & 0 & 0 & 0 & 49,45 & 17,22 \\
\hline kopertis-5A & 0 & 0 & 0 & 0 & 0 & 0 \\
\hline kopertis-6A & 0 & 0 & 0 & 0 & 0 & 0 \\
\hline kopertis-7A & 0 & $20.141,90$ & $29.132,00$ & 0 & 77,16 & 0 \\
\hline kopertis-8A & 0 & 0 & 0 & 0 & 0 & 0 \\
\hline kopertis-9A & 81,77 & $6.830,97$ & $104.129,50$ & 0 & 12,55 & 886,78 \\
\hline kopertis-10A & 66,94 & 575,13 & 316,66 & 0 & 10,84 & 0 \\
\hline kopertis-11A & 0 & 0 & 0 & 0 & 0 & 0 \\
\hline kopertis-12A & 0 & 0 & 0 & 0 & 0 & 0 \\
\hline
\end{tabular}

(continue of table-11)

\begin{tabular}{|l|c|c|c|c|c|c|}
\hline DMU Name & $\begin{array}{c}\text { S2 } \\
\text { Lecturer }\end{array}$ & $\begin{array}{c}\text { S3 } \\
\text { Lecturer }\end{array}$ & $\begin{array}{c}\text { Sp } \\
\text { Lecturer }\end{array}$ & $\begin{array}{c}\text { profesi } \\
\text { Lecturer }\end{array}$ & $\begin{array}{c}\text { Part timer } \\
\text { Lecturer }\end{array}$ & $\begin{array}{c}\text { Num,ber of } \\
\text { Lecturer }\end{array}$ \\
\hline kopertis-1 & $2.109,69$ & 388,43 & 109,54 & 143,29 & 0,48 & $3.158,54$ \\
\hline kopertis-2 & 881,50 & 293,07 & 0 & 34,02 & 0 & $1.218,60$ \\
\hline kopertis-3 & 0 & 0 & 0 & 0 & 0 & 0 \\
\hline koperttis-4 & $1.651,83$ & $1.604,27$ & 0 & 25,35 & 0 & $3.460,74$ \\
\hline kopertis-5 & $1.458,99$ & 733,77 & 42,83 & 1,11 & 1,17 & $2.409,42$ \\
\hline kopertis-6 & $2.384,34$ & 503,67 & 0 & 46,80 & 0 & $3.149,52$ \\
\hline kopertis-7 & $2.681,77$ & 839,12 & 74,09 & 113,50 & 9,82 & $4.088,80$ \\
\hline kopertis-8 & $1.762,88$ & 353,01 & 14,09 & 50,27 & 1,03 & $2.457,58$ \\
\hline kopertis-9 & $2.649,33$ & 760,87 & 0 & 112,39 & 0 & $4.191,00$ \\
\hline kopertis-10 & $1.047,01$ & 453,02 & 0 & 70,12 & 0 & $1.572,33$ \\
\hline kopertis-11 & 0 & 0 & 0 & 0 & 0 & 0 \\
\hline kopertis-12 & 0 & 0 & 0 & 0 & 0 & 0 \\
\hline
\end{tabular}




\begin{tabular}{|l|c|c|c|c|c|c|} 
kopertis-1A & 0 & 0 & 0 & 0 & 0 & 0 \\
\hline kopertis-2A & $1.260,19$ & 0 & 0 & 80,87 & 831,40 & $3.912,59$ \\
\hline kopertis-3A & $1.991,14$ & 152,91 & 0 & 74,52 & $1.257,33$ & $6.368,38$ \\
\hline koperttis-4A & $1.198,02$ & 482,77 & 0 & 0 & 427,35 & $2.174,81$ \\
\hline kopertis-5A & 0 & 0 & 0 & 0 & 0 & 0 \\
\hline kopertis-6A & 0 & 0 & 0 & 0 & 0 & 0 \\
\hline kopertis-7A & 325,03 & 0 & 0 & 46,07 & $1.154,71$ & $1.602,97$ \\
\hline kopertis-8A & 0 & 0 & 0 & 0 & 0 & 0 \\
\hline kopertis-9A & 328,18 & 118,35 & 0 & 49,77 & 0 & $1.395,62$ \\
\hline kopertis-10A & 60,94 & 0 & 0 & 61,51 & 0 & 133,29 \\
\hline kopertis-11A & 0 & 0 & 0 & 0 & 0 & 0 \\
\hline kopertis-12A & 0 & 0 & 0 & 0 & 0 & 0 \\
\hline
\end{tabular}

At the table-11 slack of scenario-4, it seen of production inputs factors that efficient use are having a slack value of zero, while the use of production input factors are have not efficient, it slack value not equal to zero. As relatively, production input factor that nearly efficient are number of institutions, number of lecturer with D3 educated, number of lecturer with SP educated and number of part time lecturer. Public higher education more efficient in use production input factor of number of institutions, number of lecturer with D3 educated, and number of part time lecturer compared to private higher education. Privare higher education more efficient in use production input factor at number of lecturer with SP educated, compared to public higher education. Based on above scenario, use of production factor of lecturer with with S2, S3 and profession education have not efficient, its indicated by the slack number are still big.

Thus, the strategic innovation to improve the efficiency of education in each Kopertis are as follows:

1. Empower and increase the use of university lecturers with S2, S3 and professions eduaction.

2. Increase the use of idle capacity of facilities and infrastructure at each higher education institution.

3. Provide opportunities profusely, and systematically of the lecturer who will conduct further studies to pursue S2 (masteral degree) and S3(doctoral degree).

4. Conduct the bench marking education administration to the efficient of kopertis region.

\section{CONCLUSIONS}

1. In Scenario 1, for the cumulative data of higher education, in terms of the management of higher education, Kopertis regions that had have efficient are 7 areas, namely: Kopertis-2, Kopertis-3, Kopertis-5, Kopertis-6, Kopertis-10, Kopertis-11 and Kopertis-12. Five Kopertis of the rest have not efficient.

2. In scenario 2, shown only 3 Kopertis regions have efficient, those are Kopertis-3, Kopertis-11 and Kopertis-12. The rest of kopertis region have not efficient.

3. In scenario 3, indicate that 9 kopertis region have been efficient. While the rest of kopertis region have not efficient, those are kopertis- 4 , kopertis- 9 and kopertis-10. 
4. At scenario-4, shown there are 3 kopertis regions for public higher education that have efficient (kopertis-3, kopertis11 dan kopertis-12) and 6 kopertis regions for private higher education that have efficient (kopertis-1,kopertis5,kopertis-6, kopertis-8,kopertis-11 dan kopertis-12). Its means, there are 9 kopertis regions have efficient of 24 kopertis DMU.

5. As over all, use of production input factors of lecturer with S2, S3 and profession education have not efficient, it seen by the slack number are still big.

6. Management of private higher education more efficient compared to management of public higher education.

\section{REFERENCES}

Ahn, T., Charnes, A. \& Cooper, W.W. (1988). Some statistical and DEA evaluations of relative efficiencies of public and private institutions of higher learning. SocioEconomic Planning Sciences, Vol. 22, No. 6, pp. 259-269.

Altamirano-Corro et al .(2012).Measuring the institutional efficiency using data envelopment analysis and analytic hierarchy process: The case of a Mexican UniversityAltamirano-Corro

Antonio. African Journal of Business Management Vol. 6(50), pp. 11923-11930, 19 December, 2012 .Available online at http://www.academicjournals.org/AJBM. DOI: 10.5897/AJBM10.770. ISSN 1993-8233 @ 2012 Academic Journals

BAN-PT. Web site .(2015). http://ban-pt.kemdiknas.go.id/

Charnes, A.W., Cooper, W.W. \& Rhodes, E.(1978). Measuring Efficiency of Decision Making Units. European Journal of Operational Research, Vol. 2, pp. 429444.

Emilio Martin .(2003). An Application of the Data Envelopment Analysis Methodology in the Performance Assessment of the Zaragoza University Departments. Retrieved from: http://www.dteconz.unizar.es/DT2003-06.pdf

Handaru Jati.(April,2015). Penilaian efisiensi Universitas LPTK di Indonesia Dengan Menggunakan Data Envelopment Analysis. Program Studi Pendidikan Teknik Informatika, Universitas Negeri Yogyakarta. Retrieved from: http://staff.uny.ac.id/sites/default/files /penelitian/Handaru\%20Jati,\%20ST.,M.M,\%20M.T,\%20Ph.D/Penilaian\%20Efisiensi \%20Universitas\%20LPTK\%20di\%20Indonesia\%20dengan\%20Data\%20Envelopmen t\%20Analysis\%20.pdf

Martin Flégl \& Kristýna Vltavská. (2013). Efficiency at Faculties of Economicsin the Czech Public Higher Education Institutions: Two Different Approaches. Department of Systems Engineering, Faculty of Economics and Management, Czech University of Life Sciences Prague, Prague, Czech Republic. 2013 Online Published: September 26, 2013. doi:10.5539/ies.v6n10p1 URL: http://dx.doi.org/10.5539/ies.v6n10p1. International Education Studies; Vol. 6, No. 10; 2013. ISSN 1913-9020 E-ISSN 19139039 .Published by Canadian Centerof Science and Education. 
Ozcan, Yasar A. (2008), "Health Care Benchmarking and Performance Evaluation", Springer, New York

Panday, Rorim .(2014). Quality Assurance Implementation In Higher Education To Strengthen The Innovation Strategy In Facing Globalization: A Case Study. Paper presented at ICOI-2014, 12-14 agustus,, De la Salle, Manila, Philipine

Pusat Data dan Statistik Pendidikan.(2012).Statistik Perguruan Tinggi (PT) Tahun 2011/2012. Sekretaris Jenderal Kementerian Pendidikan dan Kebudayaan Republik Indonesia.

Sistem Pendidikan Nasional.(2003).Undang-undang Republik Indonesia Nomor 20 Tahun 2003 tentang Sistem Pendidikan Nasional

Standar Nasional Pendidikan.(2005). Peraturan Pemerintah Nomor 19 tahun 2005 tentang Standar Nasional Pendidikan.

Undang-undang Guru dan Dosen.(2005). Undang-undang Republik Indonesia Nomor 14 Tahun 2005 tentang Guru dan Dosen.

Zara Daghbashyan.(2011).The Economic Efficiency of Swedish Higher Education Institutions. Division of Economics CESIS, KTH, CESIS Electronic Working Paper Series.Paper No. 245.The Royal Institute of technology Centre of Excellence for Science and Innovation Studies (CESIS). http://www.cesis.se

\section{ATTACHMENTS}

Tabel-1 Cummulative data for all higher education

\begin{tabular}{|l|c|c|c|c|c|c|}
\hline DMU Name & $\begin{array}{c}\text { Number } \\
\text { of } \\
\text { institution }\end{array}$ & $\begin{array}{c}\text { New } \\
\text { Student }\end{array}$ & $\begin{array}{c}\text { Registerd } \\
\text { student }\end{array}$ & Graduate & $\begin{array}{c}\text { Number } \\
\text { of } \\
\text { Lecturer }\end{array}$ & $\begin{array}{c}\text { D3 } \\
\text { lecturer }\end{array}$ \\
\hline kopertis-1 & 360 & 87633 & 542990 & 57059 & 20290 & 179 \\
\hline kopertis-2 & 218 & 53800 & 341379 & 35933 & 11239 & 52 \\
\hline kopertis-3 & 339 & 303325 & 1029117 & 217643 & 22767 & 147 \\
\hline koperttis-4 & 496 & 138627 & 758489 & 86070 & 28795 & 123 \\
\hline kopertis-5 & 126 & 55196 & 244158 & 38866 & 9280 & 11 \\
\hline kopertis-6 & 253 & 89346 & 397460 & 57647 & 15101 & 58 \\
\hline kopertis-7 & 341 & 146746 & 693926 & 86298 & 25216 & 116 \\
\hline kopertis-8 & 146 & 41459 & 264087 & 28844 & 11210 & 21 \\
\hline kopertis-9 & 359 & 89427 & 582525 & 51288 & 21047 & 48 \\
\hline kopertis-10 & 258 & 61749 & 361260 & 39246 & 12345 & 39 \\
\hline kopertis-11 & 174 & 45032 & 256364 & 25728 & 9395 & 24 \\
\hline kopertis-12 & 100 & 30495 & 144915 & 13638 & 6259 & 6 \\
\hline
\end{tabular}


(continue of table-1)

\begin{tabular}{|l|c|c|c|c|c|c|}
\hline DMU Name & $\begin{array}{c}\text { D4/S1 } \\
\text { Lecturer }\end{array}$ & $\begin{array}{c}\text { S2 } \\
\text { lecturer }\end{array}$ & $\begin{array}{c}\text { S3 } \\
\text { Lecturer }\end{array}$ & $\begin{array}{c}\text { Sp } \\
\text { Lecturer }\end{array}$ & $\begin{array}{c}\text { Profesi } \\
\text { Lecturer }\end{array}$ & $\begin{array}{c}\text { Part time } \\
\text { Lecturer }\end{array}$ \\
\hline kopertis-1 & 7062 & 6205 & 806 & 243 & 276 & 5519 \\
\hline kopertis-2 & 3600 & 4617 & 672 & 86 & 156 & 2056 \\
\hline kopertis-3 & 6808 & 9722 & 2258 & 682 & 227 & 2923 \\
\hline koperttis-4 & 8287 & 11840 & 3281 & 179 & 177 & 4908 \\
\hline kopertis-5 & 1840 & 5001 & 1509 & 138 & 50 & 731 \\
\hline kopertis-6 & 3667 & 8221 & 1304 & 131 & 231 & 1489 \\
\hline kopertis-7 & 6321 & 11676 & 2345 & 306 & 249 & 4103 \\
\hline kopertis-8 & 3246 & 5412 & 830 & 83 & 133 & 1485 \\
\hline kopertis-9 & 6594 & 8948 & 1800 & 98 & 291 & 3268 \\
\hline kopertis-10 & 3649 & 5650 & 950 & 77 & 220 & 1754 \\
\hline kopertis-11 & 2669 & 4392 & 542 & 29 & 74 & 1665 \\
\hline kopertis-12 & 1943 & 2646 & 220 & 11 & 17 & 688 \\
\hline
\end{tabular}

Table-2 Public higher education data

\begin{tabular}{|l|c|c|c|c|c|}
\hline DMU Name & $\begin{array}{c}\text { Number } \\
\text { of } \\
\text { institution }\end{array}$ & $\begin{array}{c}\text { New } \\
\text { Student }\end{array}$ & $\begin{array}{c}\text { Registerd } \\
\text { student }\end{array}$ & Graduate & $\begin{array}{c}\text { D3 } \\
\text { lecturer }\end{array}$ \\
\hline kopertis-1 & 6 & 27513 & 109744 & 18257 & 2 \\
\hline kopertis-2 & 7 & 20748 & 81362 & 10310 & 12 \\
\hline kopertis-3 & 5 & 170821 & 554952 & 146252 & 0 \\
\hline koperttis-4 & 8 & 54701 & 162949 & 30617 & 6 \\
\hline kopertis-5 & 3 & 20812 & 90746 & 14460 & 3 \\
\hline kopertis-6 & 6 & 31579 & 125898 & 18649 & 5 \\
\hline kopertis-7 & 11 & 41808 & 179448 & 23661 & 0 \\
\hline kopertis-8 & 8 & 18838 & 72920 & 9910 & 2 \\
\hline kopertis-9 & 11 & 39038 & 153100 & 21546 & 6 \\
\hline kopertis-10 & 10 & 30675 & 132944 & 18210 & 3 \\
\hline kopertis-11 & 10 & 25514 & 96034 & 11282 & 4 \\
\hline kopertis-12 & 7 & 14985 & 56294 & 5087 & 0 \\
\hline
\end{tabular}

(continue of table-2)

\begin{tabular}{|l|c|c|c|c|c|c|c|}
\hline DMU Name & $\begin{array}{c}\text { D4/S1 } \\
\text { Lecturer }\end{array}$ & $\begin{array}{c}\text { S2 } \\
\text { lecturer }\end{array}$ & $\begin{array}{c}\text { S3 } \\
\text { Lecturer }\end{array}$ & $\begin{array}{c}\text { Sp } \\
\text { Lecturer }\end{array}$ & $\begin{array}{c}\text { Profesi } \\
\text { Lecturer }\end{array}$ & $\begin{array}{c}\text { Part } \\
\text { time } \\
\text { Lecturer }\end{array}$ & $\begin{array}{c}\text { Number } \\
\text { of } \\
\text { Lecturer }\end{array}$ \\
\hline kopertis-1 & 569 & 2976 & 645 & 213 & 191 & 4 & 4600 \\
\hline kopertis-2 & 378 & 2225 & 523 & 31 & 57 & 9 & 3235 \\
\hline kopertis-3 & 284 & 1577 & 893 & 445 & 38 & 21 & 3258 \\
\hline koperttis-4 & 860 & 4025 & 2172 & 96 & 62 & 16 & 7237 \\
\hline kopertis-5 & 243 & 1990 & 1013 & 107 & 6 & 4 & 3366 \\
\hline kopertis-6 & 367 & 3758 & 896 & 82 & 75 & 8 & 5191 \\
\hline kopertis-7 & 630 & 4443 & 1488 & 221 & 181 & 20 & 6983 \\
\hline kopertis-8 & 479 & 3043 & 673 & 72 & 86 & 4 & 4359 \\
\hline kopertis-9 & 1170 & 5050 & 1352 & 84 & 180 & 15 & 7957 \\
\hline kopertis-10 & 643 & 2992 & 767 & 54 & 98 & 9 & 4566 \\
\hline kopertis-11 & 711 & 2998 & 467 & 23 & 62 & 34 & 4299 \\
\hline kopertis-12 & 788 & 1929 & 184 & 10 & 14 & 2 & 2927 \\
\hline
\end{tabular}


Table-3 Private higher education data

\begin{tabular}{|l|c|c|c|c|c|}
\hline DMU Name & $\begin{array}{c}\text { Number } \\
\text { of } \\
\text { institution }\end{array}$ & $\begin{array}{c}\text { New } \\
\text { Student }\end{array}$ & $\begin{array}{c}\text { Registerd } \\
\text { student }\end{array}$ & Graduate & $\begin{array}{c}\text { D3 } \\
\text { lecturer }\end{array}$ \\
\hline kopertis-1 & 354 & 60120 & 433246 & 38802 & 177 \\
\hline kopertis-2 & 211 & 33052 & 260017 & 25623 & 40 \\
\hline kopertis-3 & 334 & 132504 & 474165 & 71391 & 147 \\
\hline koperttis-4 & 488 & 83926 & 595540 & 55453 & 117 \\
\hline kopertis-5 & 123 & 34384 & 153412 & 24406 & 8 \\
\hline kopertis-6 & 247 & 57767 & 271562 & 38998 & 53 \\
\hline kopertis-7 & 330 & 104938 & 514478 & 62637 & 116 \\
\hline kopertis-8 & 138 & 22621 & 191167 & 18934 & 19 \\
\hline kopertis-9 & 348 & 50389 & 429425 & 29742 & 42 \\
\hline kopertis-10 & 248 & 31074 & 228316 & 21036 & 36 \\
\hline kopertis-11 & 164 & 19518 & 160330 & 14446 & 20 \\
\hline kopertis-12 & 93 & 15510 & 88621 & 8551 & 6 \\
\hline
\end{tabular}

(continue of table-3)

\begin{tabular}{|l|c|c|c|c|c|c|c|}
\hline DMU Name & $\begin{array}{c}\text { D4/S1 } \\
\text { Lecturer }\end{array}$ & $\begin{array}{c}\text { S2 } \\
\text { lecturer }\end{array}$ & $\begin{array}{c}\text { S3 } \\
\text { Lecturer }\end{array}$ & $\begin{array}{c}\text { Sp } \\
\text { Lecturer }\end{array}$ & $\begin{array}{c}\text { Profesi } \\
\text { Lecturer }\end{array}$ & $\begin{array}{c}\text { Part } \\
\text { time } \\
\text { Lecturer }\end{array}$ & $\begin{array}{c}\text { Number } \\
\text { of } \\
\text { Lecturer }\end{array}$ \\
\hline kopertis-1 & 6493 & 3229 & 161 & 30 & 85 & 5515 & 15690 \\
\hline kopertis-2 & 3222 & 2392 & 149 & 55 & 99 & 2047 & 8004 \\
\hline kopertis-3 & 6524 & 8145 & 1365 & 237 & 189 & 2902 & 19509 \\
\hline koperttis-4 & 7427 & 7815 & 1109 & 83 & 115 & 4892 & 21558 \\
\hline kopertis-5 & 1597 & 3011 & 496 & 31 & 44 & 727 & 5914 \\
\hline kopertis-6 & 3300 & 4463 & 408 & 49 & 156 & 1481 & 9910 \\
\hline kopertis-7 & 5691 & 7233 & 857 & 85 & 168 & 4083 & 18233 \\
\hline kopertis-8 & 2767 & 2369 & 157 & 11 & 47 & 1481 & 6851 \\
\hline kopertis-9 & 5424 & 3898 & 348 & 14 & 111 & 3253 & 13090 \\
\hline kopertis-10 & 3006 & 2658 & 189 & 23 & 122 & 1745 & 7779 \\
\hline kopertis-11 & 1958 & 1394 & 75 & 6 & 12 & 1631 & 5096 \\
\hline kopertis-12 & 1155 & 717 & 36 & 1 & 3 & 1414 & 3332 \\
\hline
\end{tabular}

Table-4 Public and private higher education data

\begin{tabular}{|l|c|c|c|c|c|}
\hline DMU Name & $\begin{array}{c}\text { Number } \\
\text { of } \\
\text { institution }\end{array}$ & $\begin{array}{c}\text { New } \\
\text { Student }\end{array}$ & $\begin{array}{c}\text { Registerd } \\
\text { student }\end{array}$ & Graduate & $\begin{array}{c}\text { D3 } \\
\text { lecturer }\end{array}$ \\
\hline kopertis-1 & 6 & 27513 & 109744 & 18257 & 2 \\
\hline kopertis-2 & 7 & 20748 & 81362 & 10310 & 12 \\
\hline kopertis-3 & 5 & 170821 & 554952 & 146252 & 0 \\
\hline koperttis-4 & 8 & 54701 & 162949 & 30617 & 6 \\
\hline kopertis-5 & 3 & 20812 & 90746 & 14460 & 3 \\
\hline kopertis-6 & 6 & 31579 & 125898 & 18649 & 5 \\
\hline kopertis-7 & 11 & 41808 & 179448 & 23661 & 0 \\
\hline kopertis-8 & 8 & 18838 & 72920 & 9910 & 2 \\
\hline kopertis-9 & 11 & 39038 & 153100 & 21546 & 6 \\
\hline kopertis-10 & 10 & 30675 & 132944 & 18210 & 3 \\
\hline
\end{tabular}




\begin{tabular}{|l|c|c|c|c|c|} 
kopertis-11 & 10 & 25514 & 96034 & 11282 & 4 \\
\hline kopertis-12 & 7 & 14985 & 56294 & 5087 & 0 \\
\hline kopertis-1A & 354 & 60120 & 433246 & 38802 & 177 \\
\hline kopertis-2A & 211 & 33052 & 260017 & 25623 & 40 \\
\hline kopertis-3A & 334 & 132504 & 474165 & 71391 & 147 \\
\hline koperttis-4A & 488 & 83926 & 595540 & 55453 & 117 \\
\hline kopertis-5A & 123 & 34384 & 153412 & 24406 & 8 \\
\hline kopertis-6A & 247 & 57767 & 271562 & 38998 & 53 \\
\hline kopertis-7A & 330 & 104938 & 514478 & 62637 & 116 \\
\hline kopertis-8A & 138 & 22621 & 191167 & 18934 & 19 \\
\hline kopertis-9A & 348 & 50389 & 429425 & 29742 & 42 \\
\hline kopertis-10A & 248 & 31074 & 228316 & 21036 & 36 \\
\hline kopertis-11A & 164 & 19518 & 160330 & 14446 & 20 \\
\hline kopertis-12A & 93 & 15510 & 88621 & 8551 & 6 \\
\hline
\end{tabular}

(continue of table-4)

\begin{tabular}{|l|c|c|c|c|c|c|c|}
\hline DMU Name & $\begin{array}{c}\text { D4/S1 } \\
\text { Lecturer }\end{array}$ & S2 lecturer & $\begin{array}{c}\text { S3 } \\
\text { Lecturer }\end{array}$ & $\begin{array}{c}\text { Sp } \\
\text { Lecturer }\end{array}$ & $\begin{array}{c}\text { Profesi } \\
\text { Lecturer }\end{array}$ & $\begin{array}{c}\text { Part time } \\
\text { Lecturer }\end{array}$ & $\begin{array}{c}\text { Number } \\
\text { of } \\
\text { Lecturer }\end{array}$ \\
\hline kopertis-1 & 569 & 2976 & 645 & 213 & 191 & 4 & 4600 \\
\hline kopertis-2 & 378 & 2225 & 523 & 31 & 57 & 9 & 3235 \\
\hline kopertis-3 & 284 & 1577 & 893 & 445 & 38 & 21 & 3258 \\
\hline koperttis-4 & 860 & 4025 & 2172 & 96 & 62 & 16 & 7237 \\
\hline kopertis-5 & 243 & 1990 & 1013 & 107 & 6 & 4 & 3366 \\
\hline kopertis-6 & 367 & 3758 & 896 & 82 & 75 & 8 & 5191 \\
\hline kopertis-7 & 630 & 4443 & 1488 & 221 & 181 & 20 & 6983 \\
\hline kopertis-8 & 479 & 3043 & 673 & 72 & 86 & 4 & 4359 \\
\hline kopertis-9 & 1170 & 5050 & 1352 & 84 & 180 & 15 & 7957 \\
\hline kopertis-10 & 643 & 2992 & 767 & 54 & 98 & 9 & 4566 \\
\hline kopertis-11 & 711 & 2998 & 467 & 23 & 62 & 34 & 4299 \\
\hline kopertis-12 & 788 & 1929 & 184 & 10 & 14 & 2 & 2927 \\
\hline kopertis-1A & 6493 & 3229 & 161 & 30 & 85 & 5515 & 15690 \\
\hline kopertis-2A & 3222 & 2392 & 149 & 55 & 99 & 2047 & 8004 \\
\hline kopertis-3A & 6524 & 8145 & 1365 & 237 & 189 & 2902 & 19509 \\
\hline koperttis-4A & 7427 & 7815 & 1109 & 83 & 115 & 4892 & 21558 \\
\hline kopertis-5A & 1597 & 3011 & 496 & 31 & 44 & 727 & 5914 \\
\hline kopertis-6A & 3300 & 4463 & 408 & 49 & 156 & 1481 & 9910 \\
\hline kopertis-7A & 5691 & 7233 & 857 & 85 & 168 & 4083 & 18233 \\
\hline kopertis-8A & 2767 & 2369 & 157 & 11 & 47 & 1481 & 6851 \\
\hline kopertis-9A & 5424 & 3898 & 348 & 14 & 111 & 3253 & 13090 \\
\hline kopertis-10A & 3006 & 2658 & 189 & 23 & 122 & 1745 & 7779 \\
\hline kopertis-11A & 1958 & 1394 & 75 & 6 & 12 & 1631 & 5096 \\
\hline kopertis-12A & 1155 & 717 & 36 & 1 & 3 & 1414 & 3332 \\
\hline
\end{tabular}

